\title{
LIMINARES
}

\section{Antonio GAMONEDA}

L

a Universidad Autónoma de Madrid, en organización compartida con la Saint Louis University, la Sociedad Estatal de Conmemoraciones Culturales y la Dirección General del Libro, Archivos y Bibliotecas del Ministerio de Cultura, con la colaboración también de la Biblioteca Nacional de España, acogiendo con generosidad el, a su vez, generoso impulso del profesor Rafael Morales Barba, con cuyo padre mantuve una hermosa amistad, ha querido llevar a la realidad, dentro del curso lectivo 2008-2009, el congreso que, bajo el lema «Poesía y Divergencia VII. Antonio Gamoneda (La palabra dañada)», se ha ocupado de mi escritura, precisa y naturalmente de aquella que pretende adentrarse en la especie poética. Este libro resulta de las ponencias presentadas en el mencionado congreso.

El admirado, por admirable, elenco de ponentes debiera ser nombrado aquí uno por uno para personalizar debidamente mi agradecimiento, pero esta nota, que no es de autor ni de editor, sino de beneficiado; que no es protocolaria aunque estaría muy justificado que lo fuese, dentro, claro está, de una verídica sinceridad, tiene que ser -me lo dice el sentido común- razonablemente breve. Trucaré con timidez esta conveniencia señalando por su nombre y justificándome en su edad dos pilares extremos de este arco del saber. Uno de ellos será el profesor doctor don Antonio García Berrio, el mayor en edad y experiencia; el otro lo localizaré en la mayor juventud, que es la de Carlota FernándezJáuregui Rojas, que, pobre de mí, prepara ahora mismo su tesis doctoral sobre las relaciones y diferencias entre la poesía de César Vallejo y la mía. En el recorrido del arco, ya lo tengo dicho, una nutrida serie de nombres cargados de sabiduría creativa.

De sabiduría. Tengo que decirlo: la sabiduría me produce admiración y... temor. Temor, ¿por qué? Intentaré decirlo.

Por lo que concierne al universo poético, yo me he preparado una mínima «cosmología» que todo lo resuelve y explica no resolviendo ni explicando nada. Yo me aferro a una suprema expresión de Juan de Yepes, el frailecito cuidadosamente apaleado por los Calzados de Toledo, que la católica, apostólica y romana convirtió, con avisada justicia, en San Juan de la Cruz, quizá para procurar un alivio ecuménico a la historicidad del apaleo.

La frasecita es bien conocida: «un no saber sabiendo», matizada repetidamente en otras como «un entender no entendiendo»o «un no sé qué que quedan balbuciendo» (qué prodigiosa cacofonía la 
de esta tercera, ¿no les parece?) que ha sido - han sido, que he dado tres- seriamente sometida (sometidas) a estudio por incontables especialistas entre los que, muy probablemente, estará alguno de los componentes del Congreso. Pues bien, yo no he investigado, no he entrado nunca, porque no sé ni quiero, en profunda ni metódica hermenéutica; yo me he atenido al pie de la letra al «no saber» y he colocado el «sabiendo» en el terreno de las hipótesis convenientes, pensando en el caso de los poetas verazmente egregios.

Sé que San Juan de la Cruz - todo el mundo lo sabe , que explicó largamente y a la defensiva todas sus insurgentes palabras, se refería, en los trazos poéticos que menciono, a la experiencia mística, pero todo e 1 mundo sabe también -y lo sabía mejor que nadie San Juan, que lo dice y no lo dice- que la experiencia mística no es que sea inseparable de la experiencia poética porque no sabían o no querían, y hay poetas, como ocurre en mi caso, me parece, que desconocen la mística, pero esto no implica demostración contraria. Debe bastarnos manifestaciones tan poderosas como son la Biblia (el «Cantar de los Cantares», el «Libro de Job», la profética de Jeremías, que tan bien entendió Quevedo, el «Apocalipsis»-iqué contundente modernidad la del Apocalipsis!-), la literatura sufí, los salmos náhuatl, que Fray Bernardino de Sahagún no se atrevió a traducir, y, por si les apetece contemporaneidad, ahí tienen a Simone Weil. No son más que unos pocos los que menciono, pero, ¿no comportan indicios suficientes?

Pues en esto, en el «no saber», me he quedado yo en modo simple y llano. Hagan los ponentes ya está hecho- lo suyo, y yo me «quitaré el sombrero» respetuosa y temerosamente, como digo. Iré hasta donde sepa en la comprensión y concordaré o no, aunque, por lo que retengo de la oralidad congresual, me parece que sí, que estaré en concordancia con un amplísimo casi todo, pero permaneceré en el miedo y el miedo salvará mi ignorancia. La que yo entiendo como necesaria ignorancia.

Espero que todo el saber que tanto me impresiona, y también, pobremente, todo mi «no saber» sean para bien. Lo serán. Una vez más, muchas gracias. 